\title{
PEMANFAATAN INSTAGRAM SEBAGAI MEDIA DAKWAH DI KALANGAN MAHASISWA KABUPATEN ACEH BARAT
}

\author{
Junaidi \\ Sekolah Tinggi Agama Islam Negeri Tengku Dirundeng Meulaboh
}

\begin{abstract}
The phenomenon of preaching message content on Instagram is currently a process of changing the use of media in conveying religious messages to the public. Where the use of preaching media previously was more manual (pulpit and recitation forums) in a limited context and only carried out by certain people. However, with the development of information and communication technology today, the use of dakwah media is more modern, able to reach more mad'u and can be done by anyone, especially the younger generation. This research wants to answer about how the use of Instagram among students in West Aceh Regency? This research uses a qualitative descriptive approach, the research data is collected through a process of observation, questionnaires, and in-depth interviews. The results showed, of the 55 respondents studied answered, the use of Instagram is still at the level to show self-existence with personal identity motives. Where uploads on student Instagram accounts in West Aceh are still dominant with personal content. Although they rarely upload da'wah content, some have never even accessed it at all, they often access it on other accounts, accompanied by giving likes on the content. Most of the student Instagram accounts in West Aceh District are linked to other social media accounts, such as Facebook and Twitter. This makes it easy for users to create automatic posts between Instagram and other social media accounts.
\end{abstract}

\section{Keywords}

Instagram, Media Da’wah, Sosial Media.

\section{Correspondence Contact} junaidi@staindirundeng.ac.id

\section{PENDAHULUAN}

Keberadaan fitur video di instagram saat ini tidak hanya dimanfaatkan sebagai saluran berbagi informasi semata, Tetapi juga sebagai media promosi dan dakwah. Saat ini, kontenkonten bermuatan dakwah atau pesan agama hampir setiap hari memenuhi beranda instagram. Konten-konten dakwah yang diunggah dalam bentuk video dan foto, telah memberi warna tersendiri bagi para pengguna instagram. Selain itu, hadirnya konten-konten dakwah di instagram menjadi penyeimbang bagi generasi muda Islam di tengah derasnya arus informasi saat ini. Konten-konten yang berisikan pesan dakwah di instagram sebagian besar diunggah secara personal, maupun akun resmi yang dikelola mewakili lembaga dakwah dan institusi keagamaan tertentu, seperti pondok pesantren dan perguruan tinggi keagamaan Islam.

Fenomena konten pesan dakwah di instagram merupakan suatu proses perubahan penggunaan media dalam menyampaikan pesan-pesan keagamaan kepada masyarakat. Dimana penggunaan media dakwah yang sebelumnya lebih bersifat manual (mimbar dan forum pengajian), dalam kontek terbatas dan hanya dilakukan oleh orang-orang tertentu. Namun dengan adanya perkembangan teknologi informasi dan komunikasi hari ini, 
pemanfaatan media dakwah lebih modern, mampu menjangkau lebih banyak mad'u dan dapat dilakukan oleh siapa pun, tidak terkecuali generasi muda.

Dakwah merupakan tugas setiap muslim. Hal tersebut sebagaimana diperintahkan dalam alQuran dan as-Sunnah Rasulullah SAW, kewajiban bagi setiap muslim untuk menyeru dan menyampaikan pesan agama kepada umat manusia. Di dalam al-Quran surat An-Nahl, ayat 125 Allah berfirman:

"Serulah (manusia) kepada jalan Tuhan-mu dengan hikmah dan pelajaran yang baik dan bantahlah mereka dengan cara yang baik. Sesungguhnya Tuhan-mu Dialah yang lebih mengetahui tentang siapa yang tersesat dari jalan-Nya dan Dialah yang lebih mengetahui orang-orang yang mendapat petunjuk."

Dalam islam, teknologi bukanlah suatu yang dilarang. Penggunaan media dakwah harus terus berinovasi sesuai dengan kondisi dan perkembangan zaman, sehingga pesan-pesan dakwah dapat tersampaikan dengan baik dan mudah diterima oleh setiap kalangan. Dengan adanya perkembangan teknologi hari ini, generasi muda dipandang tepat menjadi motor penggerak dakwah islam kepada masyarakat. Keberadaan telepon genggam pintar dengan segala fiturnya, jaringan internet dan media yang ada saat ini, generasi muda, khususnya mahasiswa, dapat dengan mudah mengkreasikan bebagai konten yang memuat pesan-pesan dakwah. Konten-konten tersebut nantinya dapat disebarluaskan melalui berbagai media, khususnya media sosial seperti instagram.

Pemanfaatan media sosial instagram sebagai media dakwah memiliki peranan penting, terlebih dengan melihat kondisi masyarakat hari ini yang setiap waktu terhubung dengan media sosial. Hal ini sangat memungkinkan pesan-pesan dakwah disampaikan dengan lebih sederhana, mudah, singkat, padat dan luas. Mulai dari penggabungan teks dan gambar, audio, maupun audio visual.

Selain sebagai sarana komunikasi, instagram yang sebagian besar penggunanya hari ini adalah generasi muda, juga dapat digunakan untuk mengakses konten-konten dakwah, baik untuk pengetahuan pribadi maupun saling berbagi dengan orang lain. Hal ini tentunya memberikan nilai lebih bagi kalangan mahasiswa untuk menjadi penda'i-penda'i masa kini dengan mengandalkan teknologi informasi dan komunikasi yang ada. Penelitian ini didasarkan pada motif penggunaan media komunikasi, berdasarkan pendapat McQuail yakni Informasi, Identitas, Integrasi dan Interaksi sosial, serta Hiburan.

\section{KAJIAN TEORITIK}

\section{Instagram}

Instagram merupakan sebuah aplikasi sosial yang popular di kalangan pengguna telepon pintar (smartphone). Instagram berasal dari dua suku kata "Insta" dengan kata asalnya "Instan" dan "Gram" dari kata "Telegram." Instagram merupakan penggabungan dari kata Instan-Telegram, yang memiliki arti aplikasi untuk mengirim informasi dengan cepat dalam bentuk foto. Instagram memiliki fitur untuk mengelola foto, mengedit dan membagikannya (share) ke jejaring sosial lainnya.

Kemunculan instagram sengaja diperuntukkan bagi setiap orang yang memiliki hobi di bidang fotografi. Hal ini terlihat dari menu-menu di instagram yang berfungsi untuk mengolah foto. Keberadaan fitur-fitur pengolah foto ini menjadi daya tarik tersendiri bagi para pengguna. Sebagai aplikasi photo sharing, pengguna instagram juga dapat membagikan hasil foto mereka melalui berbagai layanan media sosial lainnya, seperti facebook, twitter, whatsapp dan 
lainnya. Karena keunggulan fitur ini pula penggunaan aplikasi instagram semakin berkembang.

Para pengguna dapat mengunggah foto-foto yang diambil secara langsung dengan kamera mereka atau file foto yang tersimpan pada ponsel. Pada saat foto diunggah, pengguna dapat memilih berbagai filter efek yang tersedia di instagram sesuai keinginan. Sebagai aplikasi media sosial yang dikhususkan untuk berbagi foto, instagram memiliki keunikan dari segi batas foto berbentuk persegi. Bentuk ini memiliki kemiripan dengan gambar Kodak Instamatic dan Polaroid, dan dapat disesuaikan dengan rasio aspek 16:9 yang biasa digunakan pada kamera ponsel.

Instagram resmi dirilis pada 6 Oktober 2010, oleh Kevin Systrom dan Mike Krieger di bawah perusahaan startup Burbn, inc. Kevin Systrom dan Mike Krieger bekerja keras untuk mewujudkan layanan jejaring sosial berbasis fotografi sesuai impian mereka, hingga akhirnya mampu menghadirkan satu aplikasi photo sharing revolusioner, Instagram. Kevin Systrom dan Mike Krieger tidak jauh berbeda dengan tokoh-tokoh pendahulu seperti Stve Jobs pendiri Apple, Bill Gates pendiri Microsoft, Mark Zuckerberg pendiri Facebook, Maat Mullenweg pendiri Wordpress, Google dan sebagainya adalah para innovator teknologi kelas dunia yang telah mengembangkan produk revolusioner sejak usia muda.

Pada tanggal 3 April 2012, menjadi hari bersejarah bagi Instagram karena telah sukses berada platform di android. Jumlah pengguna Instagram sebelumnya berjumlah 30 juta bertambah 1 juta hanya dalam 12 jam dan terus meningkat. Hal ini yang membuat nilai harga Instagram sebagai layanan photo sharing dan Burbn sebagai perusahaan semakin tinggi. Pada tanggal 1 Mei 2012, jumlah pengguna menjadi 50 juta dan terus bertambah 5 juta tiap minggunya. Hanya berselang sembilan hari setelah booming kehadirannya di android, perusahaan ini diakuisi oleh facebook.

\section{Fitur Instagram}

Instagram adalah sebuah aplikasi berbagi foto dan mengambil gambar atau foto yang menerapkan filter digital untuk mengubah tampilan efek foto, dan membagikannya ke berbagai layanan media sosial, termasuk milik Instagram sendiri. Instagram memiliki lima menu utama yang semuanya terletak dibagian bawah yaitu sebagai berikut:

\section{Home Page}

Home page adalah halaman utama yang menampilkan (timeline) foto-foto terbaru dari sesama pengguna yang telah diikuti. Cara melihat foto yaitu hanya dengan menggeser layar dari bawah ke atas seperti saat scroll mouse di komputer. Kurang lebih 30 foto terbaru dimuat saat pengguna mengakses aplikasi, Instagram hanya membatasi foto-foto terbaru.

2. Comments

Sebagai layanan jejaring sosial Instagram menyediakan fitur komentar, foto- foto yang ada di Instagram dapat dikomentar di kolom komentar. Caranya tekan ikon bertanda balon komentar di bawah foto, kemudian ditulis kesan-kesan mengenai foto pada kotak yang disediakan setelah itu tekan tombol send. 
3. Explore

Explore merupakan tampilan dari foto-foto populer yang paling banyak disukai para pengguna Instagram. Instagram menggunakan algoritma rahasia untuk menentukan foto mana yang dimasukkan ke dalam explore feed.

4. Profile

Profile pengguna dapat mengetahui secara detail mengenai informasi pengguna, baik itu dari pengguna maupun sesama pengguna yang lainnya. Halaman profil bisa diakses melalui ikon kartu nama di menu utama bagian paling kanan. Fitur ini menampilkan jumlah foto yang telah di-upload, jumlah follower dan jumlah following.

5. News Feed

New feed merupakn fitur yang menampilkan notifikasi terhadap berbagai aktivitas yang dilakukan oleh pengguna Instagram. News feed memiliki dua jenis tab yaitu "Following" dan "News". Tab "following" menampilkan aktivitas terbaru pada user yang telah pengguna follow, maka tab "news" menampilkan notifikasi terbaru terhadap aktivitas para pengguna Instagram terhadap foto pengguna, memberikan komentar atau follow maka pemberitahuan tersebut akan muncul di tab ini.

Ada beberapa aktivitas yang dapat dilakukan di Instagram, yaitu sebagai berikut:

1. Follow

Follow adalah pengikut, dari pengguna Instagram pengguna satu agar mengikuti atau berteman dengan pengguna lain yang menggunakan Instagram.

2. Like

Like adalah suatu ikon dimana pengguna dapat menyukai gambar ataupun foto pada Instagram, dengan cara menekan tombol like dibagian bawah caption yang bersebelahan dengan komentar. Kedua, dengan double tap (mengetuk dua kali) pada foto yang disukai.

3. Komentar

Komentar adalah aktivitas dalam memberikan pikirannya melalui kata-kata, pengguna bebas memberikan komentar apapun terhadap foto, baik itu saran, pujian atau kritikan.

4. Mentions

Fitur ini adalah untuk menambah pengguna lain, caranya dengan menambah tanda arroba (@) dan memasukan akun instagram dari pengguna tersebut.

Pemanfaatan Media Sosial

Adapun diantara pemanfaatan media sosial yang paling sering dilakukan oleh pengguna, yaitu:

1. Mendapatkan Informasi

Banyak informasi yang dapat diperoleh melalui media sosial, seperti informasi beasiswa, lowongan pekerjaan, info seputar agama maupun hal-hal yang sedang trend yang dibicarakan banyak orang.

2. Menjalin Silaturahmi

Melalui sosial media, kita sebagai user atau pengguna dapat melakukan komunikasi meski dengan jarak yang berjauhan dengan pengguna lain sehingga terjalin silaturahmi, baik dengan orang baru, teman lama, bahkan kerabat dan keluarga. 
3. Kegiatan Sosial

Melalui media sosial, pengguna dimudahkan dalam menggalang dana bantuan untuk kegiatan sosial, hal ini dikarenakan informasi tentang penggalangan bantuan dapat dilihat dari oleh banyak orang dalam waktu yang singkat.

4. Branding

Branding merupakan kumpulan kegiatan komunikasi yang dilakukan oleh suatu perusahaan agar brand (merk) yang mereka tawarkan dikenal. Dalam perkembangan saat ini, branding tidak hanya dilakukan oleh perusahaan saja, namun meluas sampai tingkat personal (perorangan) atau yang lebih dekenal dengan personal branding.

5. Promosi

Adanya sosial media memudahkan orang mempromosikan produk atau jasa yang dimiliki. Jika dahulu untuk berjualan harus berada dipinggir jalan, sekarang dari rumah pun kita bisa berjualan dengan menggunakan media sosial.

\section{Isi Pesan Instagram}

Instagram menjadi aplikasi media sosial yang dapat memberikan informasi yang sangat cepat dan terkini. Banyak informasi yang dibagikan oleh para pengguna tentang kejadian yang baru saja terjadi yang bisa kita dapatkan, bahkan lebih cepat dibanding tayang di televisi. Hal tersebut dikarenakan para pengguna Instagram memiliki dorongan untuk mengunggah informasi tersebut dalam bentuk gambar maupun video, sehingga informasi tersebut mendapat respon dan menjadi bahan pembicaraan informatif di dunia maya. Keunikan lain yang dimiliki Instagram adalah pada durasi video, yang tidak boleh lebih dari 60 detik. Pembatasan durasi pada postingan video, memberi tantangan tersendiri bagi para pengguna dalam mengemas pesannya dengan lebih baik.

Penggunaan fitur video Instagram saat ini banyak digunakan oleh para komunitas vidgram. Biasanya mereka mengunggah video-video pribadi, informasi, komedi, fashion, dan apa yang sedang hangat diperbincangkan. Penonton dari video-video mereka sangatlah banyak, bisa mencapai satu juta lebih tayangan. Kondisi ini menjadi motivasi bagi para da'i untuk menghadirkan dakwah di antara video-video mereka kepada para pengguna Instagram dengan memanfaatkan fitur vidgram (video instagram).

Dalam proses dakwah, konten-konten bermuatan Islam dengan penyajian yang kreatif dan menarik, banyak diminati oleh pengguna Instagram. Konten-konten Islami di Instagram yang disukai, menjadi tren di masyarakat, terutama mahasiswa. Konten-konten dakwah di instagram saat ini semakin banyak ditemui. Konten Islami yang kreatif, membuat masyarakat tidak bosan, dan bahkan mereka ikut membagikan ke media sosial lainnya.

\section{Media Dakwah}

Media dakwah adalah alat yang dipakai sebagai perantara untuk melakukan kegiatan materi dakwah. Dari segi penyampaian pesan, media dakwah digolongkan menjadi tiga, yaitu: media lisan, media tulisan dan media audio visual. Dakwah hari ini dihadapkan pada perkembangan zaman dan kemajuan teknologi komunikasi. Artinya dakwah dituntut untuk sesuai dengan mad'u sehingga efektif dan efisien.

Dalam perkembangan selanjutnya terdapat media dakwah yang lebih efektif ada yang berupa media visual, audio, audio visual, buku-buku, koran, radio, televisi, drama dan sebagainya. Ada beberapa prinsip yang harus diperhatikan dalam rangka menentukan media dakwah yang tepat dalam suatu aktivitas dakwah, prinsip-prinsip tersebut adalah: 
1. Tidak ada satupun media yang paling baik.

2. Media yang dipilih sesuai dengan tujuan dakwah yang hendak dicapai.

3. Media yang dipilih sesuai dengan materi dakwah.

4. Media yang dipilih sesuai dengan sasaran dakwah

5. Pemilihan dakwah dengan cara objektif.

6. Efektifitas dan efisiensi harus diperhatikan

Walaupun dakwah selama ini diidentikkan dengan ceramah melalui media lisan (dakwah bil lisan), namun seiring perkembangan zaman, di era globalisasi ini dimana tren informasi dan komunikasi semakin canggih, media teknologi seperti internet dan media sosial akan menjadi pengganti yang efektif. Sekalipun dakwah dengan lisan masih tetap eksis, teknologi melalui media sosial akan mengambil peranan cukup signifikan dalam penyebaran pesan-pesan dakwah.

Media sosial Instagram menjadi media yang paling diminati saat ini. Hal ini dapat dilihat dari pengunduhan aplikasi di google play store yang mencapai 1 triliun lebih. Menjadi Top Media Sosial nomor 2. Maka tidak mengherankan jika instagram disebut-sebut dapat menjadi media dakwah yang efektif di tengah-tengah masyarakat, terutama mahasiswa. Hal ini dikarenakan, karakteristik generasi muda hari ini yang masuk dalam golongan milenial merupakan generasi yang selalu update dan menyukai hal-hal baru.

\section{Pendekatan Uses and Gratification}

Teori ini mengajukan gagasan bahwa perbedaan individu menyebabkan audiens mencari menggunakan dan memberikan tanggapan terhadap isi media secara berbeda-beda, yang disebabkan oleh faktor sosial dan psikologis yang berbeda diantara individu dan audien. Teori ini memfokuskan perhatian pada motivasi dan perilaku audien terhadap media, singkatnya "what do people do with the media?"

Teori ini menilai bahwa audien dalam menggunakan media berorientasi pada tujuan, bersifat aktif sekaligus deskriminatif. Teori uses and gratification ini juga menjelaskan mengenai kapan dan bagaimana audien sebagai konsumen media menjadi lebih aktif atau kurang aktif dalam menggunakan media dan akibat atau konsekuensi dari penggunaan media itu.

McQuail membagi motif penggunaan media oleh individu ke dalam empat kelompok, yaitu:

a. Motif Informasi

1) Mencari berita tentang peristiwa dan kondisi yang berkaitan dengan lingkungan terdekat, masyarakat, dan dunia.

2) Mencari bimbingan berbagai masalah praktis, pendapat, dan hal-hal yang berkaitan dengan penentuan pilihan.

3) Memuaskan rasa ingin tahu dan minat umum.

4) Belajar, pendidikan diri sendiri.

5) Memperoleh rasa damai melalui penambahan pengetahuan.

b. $\quad$ Motif Identitas Pribadi

1) Menemukan penunjang nilai-nilai pribadi.

2) Menemukan model perilaku.

3) Mengidentifikasikan diri dengan nilai-nilai lain dalam media.

4) Meningkatkan pemahaman tentang diri sendiri.

c. Motif Integrasi dan Interaksi Sosial

1) Memperoleh pengetahuan tentang keadaan orang lain.

2) Mengidentifikasikan diri dengan orang lain dan meningkatkan rasa memiliki. 
3) Menemukan bahan percakapan dan interaksi sosial.

4) Memperoleh teman selain dari manusia.

5) Membantu menjalankan peran sosial.

6) Memungkinkan diri untuk dapat menghubungi sanak keluarga, teman, dan masyarakat.

d. Motif Hiburan

1) Melepaskan diri dari permasalahan.

2) Bersantai.

3) Memperoleh kenikmatan jiwa dan estetis.

4) Mengisi waktu.

5) Penyaluran emosi.

6) Membangkitkan gairah seks.

Individu-individu menggunakan media massa karena didorong oleh motif-motif tertentu yang dicarikan pemuasannya melalui media tertentu pula, meski betapa pun kecilnya pemuasan yang dapat dilakukan media tersebut (Mauliansyah, 2018). Dari berbagai motif yang mendorong menggunakan media, akan tumbuh semacam harapan yang dicarikan pemuasannya melalui media tersebut.

\section{METODOLOGI}

Jenis penelitian yang penulis gunakan adalah deskriptif kualitatif yang bertujuan untuk melukiskan secara sistematis fakta atau karakteristik bidang tertentu secara faktual dan cermat. Terutama terkait pemanfaatan instagram sebagai media dakwah di kalangan mahasiswa di Kabupaten Aceh Barat. Untuk mendapatkan gambaran utuh tentang permasalahan yang diteliti, penulis menggabungkan data-data statistik berupa angka-angka, dengan pernyataan hasil wawancara informan penelitian.

Dalam penelitian ini, penulis menganalisis penggunaan Instagram sebagai media dakwah di kalangan mahasiswa di Kabupaten Aceh Barat. Adapun mahasiswa yang diteliti adalah mahasiswa yang berada pada sembilan perguruan tinggi di Kabupaten Aceh Barat. Para mahasiswa yang menjadi informan penelitian dipilih secara acak, dengan penyebaran quisioner penelitian dalam bentuk google form. Setelah itu, peneliti memilih beberapa informan sebagai sampel penelitian untuk dilakukan interview mengenai penggunaan media instagram sebagai media dakwah berdasarkan empat tipologi media (pengalihan, hubungan personal, indentitas pribadi dan pengawasan/pencarian informasi).

Untuk menganalisis data, penelitian ini menggunakan teknik analisis Huberman dan miles; model interaktif. Model analisis interaktif ini terdiri dari tiga hal utama, yaitu (1) reduksi data: (2) penyajian data; (3) penarikan kesimpulan atau verifikasi. Ketiga tahapan tersebut saling terkait baik sebelum, selama, dan sesudah pengumpulan data dilakukan.

\section{HASIL DAN PEMBAHASAN}

Penelitian ini melibatkan 55 mahasiswa sebagai responden/informan yang berasal dari tiga perguruan tinggi negeri di Kabupaten Aceh Barat. Jumlah tersebut merupakan responden yang mau ikut terlibat dalam penelitian yang dilakukan, berdasarkan sebaran angket google form yang dilakukan secara acak. Adapun keseluruhan responden terdiri dari mahasiswa Sekolah Tinggi Agama Islam Negeri (STAIN) Teungku Dirundeng Meulaboh sebanyak 28 orang, atau 50,9 persen. Universitas Teuku Umar (UTU) sebanyak 26 orang, atau 47,3 persen dan Akademi Komunitas Negeri (AKN) Aceh Barat sebanyak 1 orang. Dari klasifikasi jenis kelamin, 60 persen responden merupakan perempuan dan 40 persen laki-laki. 
Chart 4. Persentase Jenis Kelamin

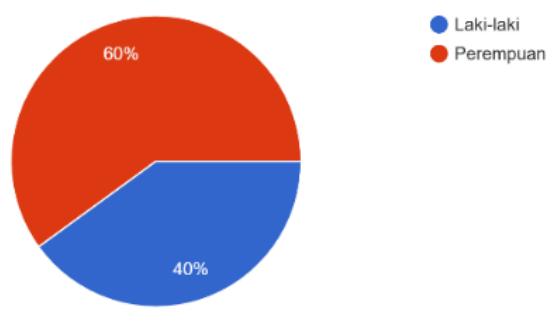

Dilihat dari sebaran program studi pada masing-masing perguruan tinggi, mahasiswa dari Program Studi Teknik Industri Universitas Teuku Umar menjadi penyumbang responden terbanyak, yakni 12 orang atau 22,3 persen. Kemudian Program Studi Ilmu Komunikasi/Komunikasi dan Penyiaran Islam Universitas Teuku Umar dan STAIN Teungku Dirundeng Meulaboh, sebanyak 7 orang atau 12,7 persen. Mahasiswa Program Studi Hukum Pidana Islam STAIN Teungku Dirundeng Meulaboh, sebanyak 5 orang atau 9,1 persen dan selebihnya merupakan sebaran dari berbagai program studi dari tiap perguruan tinggi.

Chart 5. Sebaran Program Studi

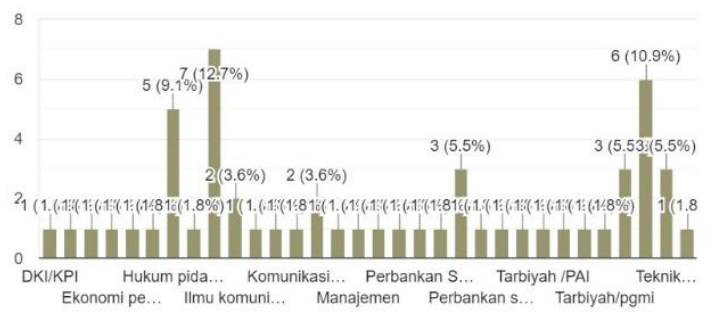

Berdasarkan tahun masuk perguruan tinggi, responden merupakan mahasiswa dengan angkatan 2014-2019. Adapun responden angkatan 2018 sebanyak 25 responden atau 45,5 persen. Angkatan 2016 sebanyak 13 orang atau 23,6 persen. Angkatan 2019 sebanyak 6 orang atau 10,9 persen. Aangakat 2017 dan 2015, memiliki persentase sama yakni 7,3 persen atau 4 mahasiswa. Sedangkan mahasiswa angkatan 2014 sebanyak 3 orang atau 4,3 persen. Dikarenakan angket penelitian ini bersifat terbuka, terdapat satu responden angkaran 2011, namun tidak memenuhi syarat karena sudah tidak berstatus mahasiswa. 
Chart 6. Tahun Masuk Responden

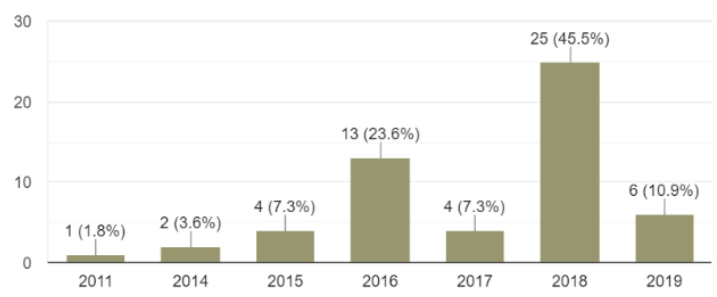

Dari segi penggunaan instagram, 26 responden atau 46,4 persen telah menggunakan aplikasi media sosial instagram dalam kurun waktu 3-4 tahun. Jumlah responden yang menggunakan instagram 1-2 tahun sebanyak 20 orang, atau 35,7 persen. Dalam jangka waktu 5 tahun sebanyak 6 orang atau 10,7 persen dan yang menggunakan aplikasi media sosial instagram kurang dari 1 tahun berjumlah 4 mahasiswa atau 7,1 persen.

\section{Chart 7. Rentang Usia Penggunaan Instagram}

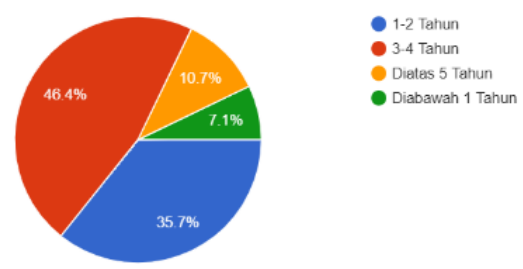

Lamanya waktu yang digunakan responden dalam mengakses Instagram sangatlah bervariasi, sebanyak 41,8 persen atau sebanyak 23 responden mengatakan hanya mengakses Instagram kurang dari satu jam perhari. Sementara itu responden yang mengaku mengakses Instagram selama 1 sampai 2 jam perhari berjumlah 32,7 persen atau 18 responden. Adapula responden yang mengakses Instagram selama 3-4 jam perhari. jumlah responden yang mengakses pada jumlah jam tersebut sebanyak 20 persen atau sebanyak 11 peserta, dan yang mengakses Instagram selama 5 Jam atau lebih perharinya berjumlah 5,5 persen atau hanya 3 dari keseluruhan responden.

Waktu akses Instagram juga sangat variative. Sebanyak 57,1 persen atau sebanyak 32 responden mengakses setiap waktu. Ada pula responden yang cenderung menggunakan Instagram diwaktu malam hari. Pengguna ini biasanya menggunakan Instagram disela watu beristirahat, berjumlah 35,7 persen atau 20 responden. Sementara waktu pagi hanya 3,6 persen atau 2 responden. Pengakses pada waktu siang dan sore masing-masing hanya berjumlah 1,8 persen atau 1 responden. Hal ini wajar terjadi, mengingat waktu aktif mahasiswa melakukan kegiatan terdapat pada siang sampai dengan sore hari. 
Chart 9. Waktu akses
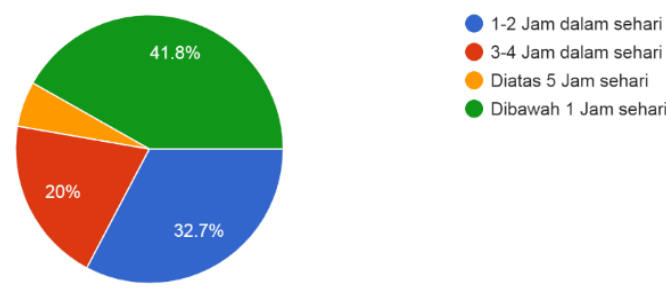

Penggunaan instagram di kalangan mahasiswa Kabupaten Aceh Barat sebagian besar masih pada motif indentitas pribadi, yaitu untuk menunjukkan eksistensi diri. Hal ini terlihat dari pilihan jawaban yang diberikan oleh 33 responden atau 61,1 persen. Dimana pemanfaatan media sosial instagram hanya untuk mengunggah konten-konten yang bersifat personal. Penggunaan instagram di kalangan mahasiswa Aceh Barat untuk mengunggah konten-konten dakwah atau religi hanya 8 orang atau 14,8 persen. Angka tersebut sama dengan jumlah yang mengunggah konten hiburan, yaitu 8 orang atau 14,8 persen. Sedangkan pemanfaatan instagram untuk mengunggah konten informasi, 5 orang atau 9,3 persen dan 0 persen untuk konten bisnis.

Chart 10. Jenis konten yang sering diunggah

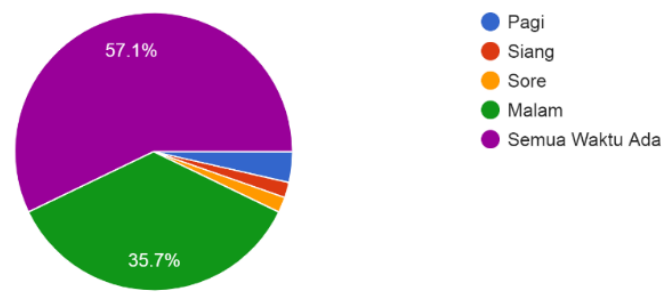

Pemanfaatan instagram di kalangan mahasiswa Kabupaten Aceh Barat menunjukkan hal yang bertolak belakang antara konten yang diunggah dengan yang diakses. Hal tersebut terlihat dari jawaban yang diberikan oleh responden terkait konten yang paling sering mereka akses. Dimana konten informasi merupakan yang paling sering diakses oleh mahasiswa di Aceh Barat, dengan angka 38,2 persen atau 21 responden.

Begitu juga halnya dengan konten dakwah, dimana 25,5 persen atau 14 responden dari mahasiswa di Aceh Barat yang diteliti, lebih sering mengakses konten dakwah daripada mengunggahnya di instagram. Untuk konten hiburan, mahasiswa Aceh Barat yang mengaksesnya sebanyak 20 persen atau 11 responden, dan konten personal 12,7 persen atau 7 responden. Sedangkan konten bisnis yang sebelumnya tidak pernah diunggah oleh mahasiswa, namun mereka mengakses konten-konten bisnis, dengan prosentase 3,6 persen atau 2 responden.

Fenomena yang terjadi belakangan ini membuat pengguna Instagram lebih cepat dalam menerima informasi kejadian-kejadian di pelosok negeri. Hal ini dikarenakan kebiasaan pengguna media sosial sering melakukan repost (membagikan ulang) konten-konten yang 
dianggap menarik. Membagikan ulang postingan konten juga biasa dilakukan oleh pengguna instagram. Hasil penelitian menunjukkan bahwa dari 55 responden yang merupakan mahasiswa di Kabupaten Aceh Barat, sebanyak 62,5 persen atau 35 responden menjawab sering merepost ulang postingan konten dakwah. Bahkan 23,2 persen atau 13 responden sangat sering melakukannya. Sedangkan yang tidak pernah melakukan repost terhadap konten dakwah sebanyak 14,3 persen atau 8 orang dari jumlah total responden.

\section{Chart 12. Persentase Repost}

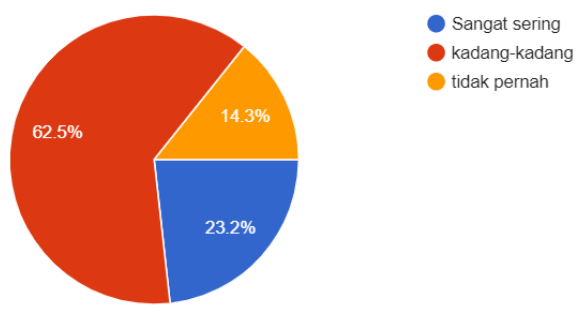

Begitu pula dalam berkomentar, kecenderungan memberikan komentar terhadap kontenkonten dakwah masih sangat rendah. Hal ini terlihat dari jawaban yang diberikan oleh responden, dimana 32,1 persen atau 18 orang memilih tidak pernah memberikan komentar pada konten-konten dakwah. Sementara 60,7 persen menjawab kadang-kadang dan hanya 7,1 persen yang menjawab sering melakukan repost terhadap konten-konten dakwah.

Chart 13. Persentase aktifitas komentar

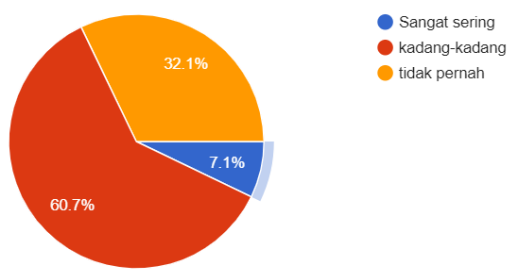

Terkait konten dakwah yang diminati dan dijadikan feed pada beranda instagram mahasiswa di Kabupaten Aceh Barat, lebih dominan pada postingan teks nasehat keagamaan, sebesar 33,9 persen atau 19 responden. Untuk konten berjenis video ceramah keagamaan responden yang meminatinya 25 persen atau 14 responden dan 8,9 persen atau 5 responden menyukai konten dakwah dalam bentuk gambar. Sedangkan 32 persen mahasiswa atau 18 responden menjawab tidak pernah mengunggah konten dakwah dalam bentuk apa pun pada akun Instagram mereka. 
Chart 14. Persentase unggahan konten

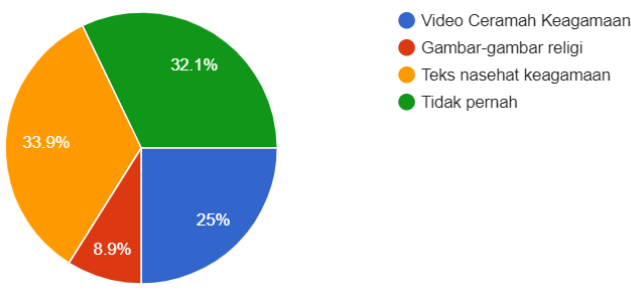

Konten-konten dakwah biasanya mereka ambil dari akun-akun keislaman yang ada di instagram, baik itu akun yang diikuti (follow) maupun yang tampil di linimasa akun mereka. Jumlah responden yang menjawab repost konten dari akun lain sebesar 64,3 persen dan yang membuat karya sendiri hanya 5.4 persen atau 3 orang dari 55 responden secara keseluruhan. Namun ada juga yang menjawab pernah melakukan keduanya, baik mengunggah ulang dari akun milik orang lain, maupun hasil karya sendiri, porsentase sebesar 30.4 persen.

Chart 15. Asal konten yang diunggah

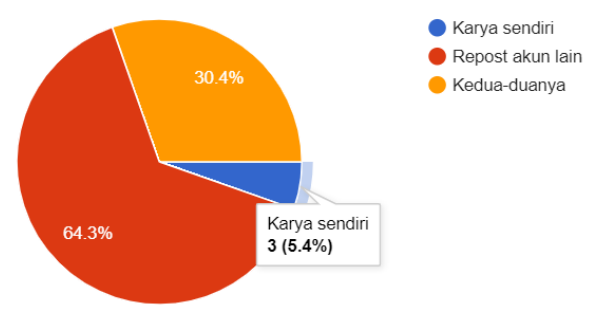

Dari jenis konten dakwah yang paling sering diakses dan diminati di instagram oleh mahasiswa di Kabupaten Aceh Barat adalah konten video ceramah keagamaan, dengan prosentase 55,4 persen atau 31 responden. Konten dengan jenis teks nasehat agama berada pada urutan kedua yang sering diakses, yaitu 23,2 persen datau 13 responden. Untuk konten dakwah dalam bentuk gambar-gambar religi sering diakses oleh 8 responden atau 14,3 persen. Sedangkan yang tidak pernah mengakses semua jenis konten dakwah yang ada di instagram tergolong tinggi, berjumlah 7,1 persen atau 4 responden.

Chart 16. Konten religi yang diakses

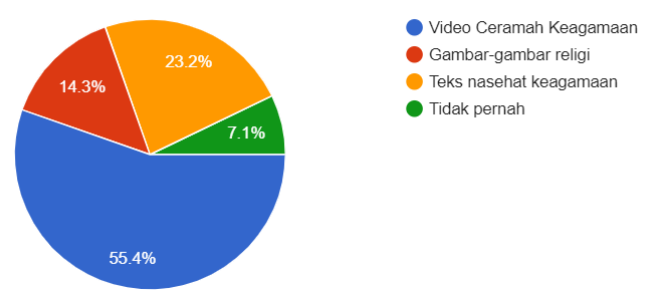

Adapun motif mahasiswa di Kabupaten Aceh Barat mengunggah dan mengakses konten dakwah di instagram yaitu, saling berbagai, ikut-ikutan, memotivasi diri dan gaya-gayaan agar 
terlihat keren. Untuk motif saling berbagi dilakukan oleh 25 persen responden atau 14 mahasiswa. Untuk motif ikut-ikutan dilakukan oleh 4 responden atau 5,4 persen. Sedangkan untuk memotivasi diri dilakukan oleh 67,9 persen responden atau 38 mahasiswa. Walaupun begitu, ada juga yang mahasiswa yang memberikan jawaban hanya untuk gaya-gayaan supaya terlihat keren.

Chart 17. Motif mengunggah dan mengakses konten dakwah

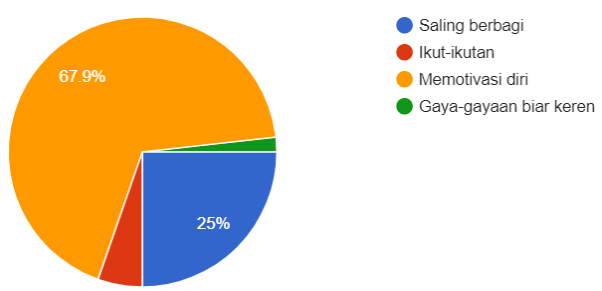

Mahasiswa di Kabupaten Aceh Barat biasanya membagikan konten dakwah dengan memanfaatkan fitur Story di instagram sebagai media berbagai. Selain itu ada juga yang menggunakan laman profil, direct message dan semua fitur yang tersedia di instagram. Adapun mahasiswa yang menggunakan fitur story berjumlah 65,5 persen (36 responden), laman profil 10,9 persen ( 6 responden), direct message 5,5 persen atau 3 responden dan penggunaan semua fitur yang ada di instagram dilakukan oleh 18,2 persen (10 responden).

Chart 18. Penggunaan fitur untuk unggahan

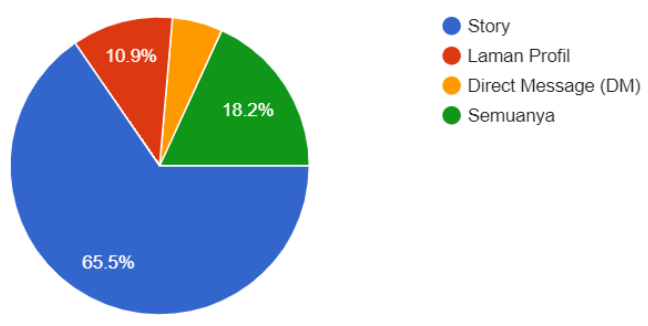

Dalam melakukan repost, mahasiswa di Kabupaten Aceh Barat cenderung lebih sering merepost video ceramah keagamaan, sebanyak 42,9 persen atau 24 responden. Teks keagamaan diminati sebanyak 25 persen atau sebanyak 14 responden. Gambar-gambar religi diminati 17,9 persen atau sebanyak 10 responden. Sedangkan 14,3 persen atau 8 responden mengaku tidak pernah melakukan repost konten religi. 
Chart 19. Konten religi yang direpost

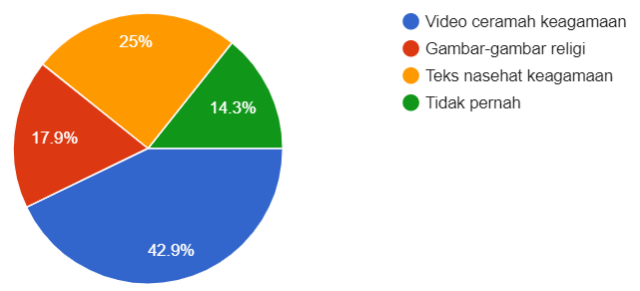

Akun Instagram mahasiswa di Aceh Barat sebagian besar terhubung dengan media sosial lainnya, seperti Facebook, Twitter, Tumbrl, dan Whatsapp. Terhubungnya akun instagram dengan akun media sosial lainnya, membuat setiap konten yang diunggah atau direpost di instagram akan secara otomatis juga terunggah di media sosial lainnya. Di kalangan mahasiswa Aceh Barat 89,1 persen atau 49 responden memiliki akun instagram mereka terhubung dengan akun facebook. Dengan kata lain, hampir 90 persen dari 55 responden menghubungkan akun Instagram mereka dengan facebook.

Chart 20. Hubungan instagram dengan media sosial lain

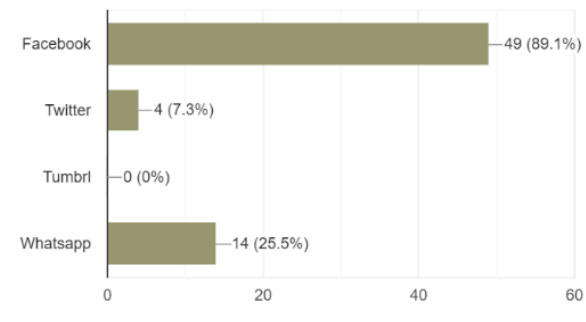

Sementara mahasiswa yang menghubungkan akun instagram mereka dengan whatsapp hanya 14 responden atau 25,5 persen. Sedangkan mahasiswa yang menghubungkan akun instagram dengan twitter hanya 7,3 persen atau 4 responden, dan tumbrl tidak terkoneksi.

Dari sekian banyak konten-konten dakwah yang ada di instagram, mahasiswa Aceh Barat paling sering memberikan tanpa suka (like) untuk konten dakwah video keagamaan, sebesar 62,5 persen atau 35 mahasiswa. Sementara 28,6 persen lainnya atau 16 mahasiswa memberikan tanda like pada konten-konten dakwah yang bersifat teks keagamaan. Untuk konten dakwah yang bersifat gambar-gambar religi, mahasiswa yang memberikan tanda suka 8,9 persen atau sebanyak 5 responden.

Chart 21. Pemberian tanda like pada konten dakwah

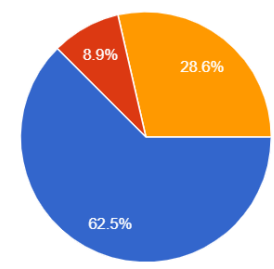

Video keagamaan - Teks nasenat reagam Tidak pernah 


\section{PEMBAHASAN}

Pesatnya perkembangan media baru saat ini tidak terlepas dari dukungan berbagai perangkat teknologi komunikasi yang memadai. Dukungan perangkat jaringan dan telekomunikasi, gawai dan mobile phone, membuat isi media bisa dengan mudah diciptakan dan disebarluaskan. Media baru telah membuka ruang bagi setiap orang untuk mengakses konten apa pun, kapan pun, di mana pun dari perangkat digital. Setiap orang bisa mendapatkan informasi dalam sekejap dari berbagai sumber di belahan dunia.

Kehadiran media baru seperti media sosial, menawarkan kapasitas untuk memperluas volume informasi yang memungkinkan individu memegang kontrol lebih besar. Hal tersebut semakin memudahkan pengguna memperoleh informasi sesuai dengan kebutuhan. Selain itu, komunikasi yang dijalin melalui media online, termasuk media sosial, tidak terbatas ruang dan waktu selama terdapat koneksi internet. Semakin maraknya situs media sosial dan seiring perkembangan teknologi, semakin banyak pula masyarakat yang menggunakannya. Hal tersebut disebabkan oleh faktor kebutuhan manusia akan informasi dan eksistensi yang tidak pernah habis. Masyarakat yang menggunakan media online dan media sosial memiliki beragam aktivitas serta kepentingan, seperti promosi, kampanye politik, bisnis dan pendidikan.

Begitu juga halnya dengan pemanfaatan media sosial instagram. Meski pada awal kemunculannya instagram dikhususkan bagi pengguna untuk bisa saling berbagai informasi melalui unggahan foto, namun seiring perkembangan dan meningkatnya kebutuhan informasi, pihak penyedia layanan telah berupaya melakukan berbagai inovasi pengembangan. Hingga saat ini, para pengguna instagram tidak hanya dapat mengunggah foto atau gambar, tapi juga video dengan berbagai fitur menarik yang disediakan.

Hadirnya fitur video di instagram kemudian dimanfaatkan oleh pengguna untuk membagikan informasi secara lebih kompleks. Dengan memanfaatkan kekuatan dan kelebihan audio visual yang dimiliki video, para pengguna instagram bisa dengan bebas mengemas berbagai jenis informasi guna mencapai target sasarannya. Mulai dari promosi bisnis, politik, pencitraan lembaga, pendidikan hingga video-video yang bermuatan pesan-pesan dakwah.

Dalam kaitannya dengan dakwah, instagram dapat diartikan sebagai sarana atau media penyampaian pesan-pesan keislaman kepada audien atau mad'u. Pemanfaatan media sosial instagram sebagai media dakwah termasuk dalam implikasi ilmu dakwah terapan, yang membutuhkan kemampuan teknis dalam mengolah pesan sehingga tersampaikan dengan baik kepada mad'u.

Penelitian yang telah penulis lakukan terhadap mahasiswa di Kabupaten Aceh Barat tentang Pemanfaatan Instagram Sebagai Media Dakwah, menunjukkan bahwa sebagian besar mahasiswa yang menggunakan instagram, belum secara maksimal memanfaatkannya sebagai media dakwah. Pemanfaatan instagram di kalangan mahasiswa Aceh Barat masih pada tataran untuk menunjukkan eksistensi diri. Unggahan-unggahan pada akun instagram mahasiswa di Aceh Barat masih dominan dengan konten-konten personal.

Padahal, jika mampu dikelola sebagai media dakwah, maka hal tersebut akan menjadi sarana efektif dalam penyampaian pesan-pesan dakwah kepada masyarakat. Hal ini dikarenakan, sebagian besar akun instagram mahasiswa di Kabupaten Aceh Barat dihubungkan dengan akun media sosial lainnya, seperti facebook dan twitter. Hal ini memberikan kemudahan bagi pengguna untuk membuat postingan otomatis antara instagram dengan akun media sosial lainnya. 
Meskipun pemanfaatan media sosial instagram sebagai media dakwah di kalangan mahasiswa di Kabupaten Aceh Barat sangat minim, bahkan ada yang tidak pernah sama sekali, namun mereka sangat sering mengaksesnya pada akun-akun lainnya. Tidak hanya sebatas mengakses, sebagian dari mereka juga memberikan tanda suka (like) pada konten tersebut dan ikut membagikan melalui feed di akun instagram mereka.

Jika dilihat dari pendapat yang dikemukakan McQuail terkait alasan penggunaan media oleh audien dalam Teori uses and gratification menunjukkan bahwa penggunaan instagram pada mahasiswa di Kabupaten Aceh Barat sebagai bentuk hubungan personal. Dimana instagram digunakan sebagai pengalih pengganti teman. Hal ini terlihat dari data rata-rata 57,1 persen atau 32 responden menggunakan instagram setiap waktu.

Penggunaan instagram di kalangan mahasiswa di Kabupaten Aceh Barat juga sebagai bentuk pengalihan (diversion) dari rutinitas sehari-hari. Hal ini terlihat bahwa 35,7 persen atau 20 responden menggunakan instagram pada malam hari, untuk menghilangkan kejenuhan aktivitas di siang hari.

Jika dilihat dari segi motif pemanfaatan instagram di kalangan mahasiswa Kabupaten Aceh Barat, rata-rata menunjukkan identitas pribadi/eksistensi diri. Hal ini terlihat dari data 33 responden atau 61,1 persen mahasiswa, memanfaatkan media sosial instagram untuk mengunggah konten-konten yang bersifat personal. Selebihnya, 14,8 persen menggunakan instagram untuk mengunggah konten-konten dakwah atau religi. Sebanyak 14,8 persen untuk mengunggah konten hiburan dan 9,3 persen untuk mengunggah konten informasi.

Dalam penelitian yang telah dilakukan, penulis penulis menemukan perbedaan pemanfaatan instagram pada saat mengunggah konten dengan mengakses konten yang dilakukan mahasiswa di Kabupaten Aceh Barat. Dimana rata-rata mahasiswa lebih sering mengakses konten informasi dibandingkan konten lainnya, dengan besaran akses 38,2 persen atau 21 responden. Begitu juga halnya dengan konten dakwah, dimana 25,5 persen atau 14 responden dari mahasiswa di Aceh Barat yang diteliti, lebih sering mengakses konten dakwah daripada mengunggahnya di instagram. Sedangkan mahasiswa Aceh Barat yang mengakses konten hiburan sebanyak 20 persen atau 11 responden. Untuk konten personal 12,7 persen atau 7 responden dan konten bisnis yang sebelumnya tidak pernah diunggah, namun diakses dengan prosentase 3,6 persen atau 2 responden.

Hal ini menunjukkan bahwa mahasiswa di Kabupaten Aceh Barat juga menggunakan media sosial instagram sebagai pengawasan. Mereka menjadikan instagram sebagai media untuk membantu mereka sebagai individu dalam mencapai sesuatu. Selain itu, juga untuk mencari berita tentang peristiwa dan kondisi yang berkaitan dengan lingkungan terdekat, masyarakat dan dunia. Mencari bimbingan berbagai masalah praktis, pendapat, dan hal-hal yang berkaitan dengan penentuan pilihan. Memuaskan rasa ingin tahu dan minat. Belajar, pendidikan diri sendiri dan memperoleh rasa damai melalui penambahan pengetahuan, terutama dari kontenkonten bermuatan dakwah, untuk memperkuat nilai-nilai individu.

Terkait konten dakwah, mahasiswa di Kabupaten Aceh Barat lebih menyenangi postingan dalam bentuk teks berupa nasehat keagamaan, sebanyak 33,9 persen atau 19 responden. Mahasiswa yang meninati konten berjenis video ceramah keagamaan, sebanyak 25 persen dan 8,9 persen menyukai konten dakwah dalam bentuk gambar. Sedangkan 32 persen mahasiswa tidak pernah mengunggah konten dakwah dalam bentuk apa pun pada akun instagram mereka.

Dari jenis konten dakwah yang paling sering diakses dan diminati di instagram oleh mahasiswa di Kabupaten Aceh Barat adalah konten video ceramah keagamaan, dengan 
prosentase 55,4 persen atau 31 responden. Konten dengan jenis teks nasehat agama berada pada urutan kedua yang sering diakses, yaitu 23,2 persen. Sedangkan 14,3 persen sering mengakses konten dakwah dalam bentuk gambar-gambar religi dan 7,1 responden tidak pernah mengakses semua jenis konten dakwah yang ada di instagram.

Adapun motif mahasiswa di Kabupaten Aceh Barat mengunggah dan mengakses konten dakwah di instagram untuk saling berbagai, ikut-ikutan, memotivasi diri dan gaya-gayaan agar terlihat keren. Konten-konten dakwah biasanya dibagikan melalui fitur Story yang ada di instagram. Selain itu, ada juga yang menggunakan laman profil, direct message dan semua fitur yang tersedia di instagram.

Dari hasil penelitian yang telah dilakukan, konten-konten dakwah yang diakses oleh mahasiswa di Kabupaten Aceh Barat melalui media sosial instagram merupakan hasil postingan dari akun-akun yang dikelola baik secara personal pendakwah (fans atau official), maupun lembaga pendidikan islam. Hanya saja, akun-akun tersebut dikelola oleh personal maupun lembaga pendidikan islam yang ada di Kabupaten Aceh Barat atau daerah lainnya di Barat Selatan Aceh. Berdasarkan hasil penelusuran yang peneliti lakukan, tidak ditemukan satu akun instagram pun yang bermuatan dakwah yang dikelola oleh pendakwah maupun lembaga pendidikan islam yang ada di Kabupaten Aceh Barat dan daerah lainnya di Kawasan Barat Selatan Aceh. Namun jika dilihat secara Aceh keseluruhan, sudah ada beberapa akun instagram yang dikelola oleh pendakwah maupun lembaga pendidikan islam, yang kontennya tentang dakwah.

Hal ini tentunya menjadi tantangan tersendiri bagi para pendakwah dan lembaga pendidikan islam yang ada di Aceh Barat dan kawasan Barat Selatan, dalam memanfaatkan berbagai saluran media dan perangkat teknologi untuk menyebarkan pesan-pesan dakwah secara lebih luas kepada masyarakat. Dalam hal ini peneliti berpendapat, penggunaan media sosial instagram sebagai media dakwah akan mampu menyentuh kelompok sasaran, terutama generasi muda. Dimana sebagian besar pengguna instagram hari ini didominasi oleh kalangan muda. Tidak adanya akun instagram yang dikelola secara khusus oleh para pendakwah dan lembaga pendidikan islam di Kabupaten Aceh Barat, maupun Kawasan Barat Selatan Aceh, tentunya juga memberikan ruang bagi penelitian selanjutnya, dalam ranah kajian ilmu dakwah, media, teknologi dan komunikasi.

\section{KESIMPULAN (Capital, Cambria, 10pt)}

Berdasarkan penelitian yang telah dilakukan tentang "Pemanfaatan Instagram Sebagai Media Dakwah di Kalangan Mahasiswa di Kabupaten Aceh Barat," dapat disimpukan bahwa, pemanfaatan instagram di kalangan mahasiswa Aceh Barat masih pada tataran untuk menunjukkan eksistensi diri. Dimana unggahan-unggahan pada akun instagram mahasiswa di Aceh Barat masih dominan dengan konten-konten personal. Hal tersebut terlihat dari jawaban yang diberikan oleh 55 responden/informan dalam penelitian ini, sebagian besar dari mereka memanfaatkan media sosial instagram untuk mengunggah konten-konten dengan motif identitas pribadi.

Meskipun mahasiswa Aceh Barat sangat minim dalam memanfaatkan media sosial instagram untuk mengunggah konten-konten dakwah, bahkan ada yang tidak pernah sama sekali, namun mereka sangat sering mengaksesnya pada akun-akun lain. Tidak hanya sebatas mengakses, bahkan sebagian dari mereka juga memberikan tanda suka (like) pada konten tersebut, dan ikut membagikan melalui feed di akun instagram mereka. Hal yang sama juga terjadi pada motif informasi, integrasi dan interaksi sosial, serta hiburan, walau dari segi unggah konten sangat kurang, namun mereka sering mengaksesnya di akun-akun lain, diikuti dengan pemberian tanda suka, walaupun tidak memberikan komentar. 
Sebagian besar akun instagram mahasiswa di Kabupaten Aceh Barat dihubungkan dengan akun media sosial lainnya, seperti Facebook dan Twitter. Hal ini memberikan kemudahan bagi pengguna untuk membuat postingan otomatis antara instagram dengan akun media sosial lainnya.

\section{DAFTAR PUSTAKA}

Atmoko, Bambang Dwi, 2012. Instagram Handbook Tips Fotografi Ponsel. Jakarta: Media Kita. Aziz, Muhammad Ali, 2004. Ilmu Dakwah. Jakarta: Kencana.

Berkowski, Gearge. 2016. How to Bulid a Billian Dollar App: Temukan Rahasia Dari Para Pengusaha Aplikasi Paling Sukses di Dunia. Tangerang: Gemilang.

Bungin, Burhan, 2007. Penenlitian Kualitatif Komunikasi, Ekonomi, Kebijakan Publik dan Ilmu Sosila Lainya, Jakarta: Prenada Media Group.

Cangara, Hafied. 2002. Pengantar Ilmu Komunikasi. Jakarta: PT. Rajagrafindo Persada.

Departeman Agama RI. 2006. Al-Quran dan Terjemahannya. CV. Pustaka Agung Harapan.

Deslima, Duli Yosieana, 2018. Pemanfaatan Instagram Sebagai Media Dakwah Bagi Mahasiswa Komunikasi dan Penyiaran Islam UIN Raden Intan Lampung. Lampung.

Enjang, Aliyudin, 2009. Dasar-Dasar Ilmu Dakwah, Bandung: Widya Padjadjaran.

Farhan, Zakiyah Romadlany. 2019. Penggunaan Instagram Sebagai Trend Media Dakwah Masa Kini (Studi Akun Instagram Pondok Pesantren Nurul Jadid)." Jawa Timur: Universitas Nurul Jadid Paiton.

Ghazali, Miliza. 2016, Buat Duit dengan Facebook dan Instagram: Panduan Menjana Pendapatan dengan Facebook dan Instagram. Malaysia: Publishing House.

Ghoni, Abdul Fahmi Muhammad, 2018. Pemanfaatan Instagram Sebagai Media Dakwah (Studi Kasus Mahasiswa Jurusan Komunikasi dan Penyiaran Islam Fakultas Dakwah dan Komunikasi UIN Walisongo Semarang). Semarang.

https://andi.link/hootsuite-we-are-social-indonesian-digital-report-2019/, diakses September 2019, pukul 00.15.

https://databoks.katadata.co.id, dan https://tekno.kompas.com, diakses pada tanggal 20 September 2018

https://databoks.katadata.co.id/datapublish/2018/02/09/berapa-pengguna-instagramdari-indonesia

https://id.wikipedia.org/wiki/Instagram\#cite note-nov2010-4

https://techno.okezone.com, diakses pada tanggal 20 September 2018

Idrus, Muhammad, 2009. Metode Penelitian Sosial. Yogyakarta: Erlangga.

Junaidi, 2016. Analisis Framing Pemeberitaan Tabloid Modus Aceh "Murthala Benturkan Zaini-Ulama". Meulaboh: STAIN Teungku Dirundeng Meulaboh.

Mauliansyah, Fiandy. 2018. Mirror on The Wall; Refleksivitas Keberpihakan Media Dalam Pemilihan Presiden Tahun 2014. Source: Jurnal Ilmu Komunikasi.

McQuail, Denis. 1991. Teori Komunikasi Massa. Jakarta: Erlangga

Morissan, Corry Andy Wardhani. 2009. Teori Komunikasi. Ghalia Indonesia. 
Morissan. 2010. Psikologi Komunikasi. Bogor: Ghalia Indonesia

Munir, M, 2006. Manajemen Dakwah. Jakarta: Kencana.

Palewa, Aprilinda Dosi, 2013. Motif Penggunaan dan Interaksi Sosial di Twitter. Yogyakarta: UIN Sunan Kalijaga.

Rohmadi, Arif, 2016. Tiga Produktif Ber-Sosial Media, Jakarta: Elex Media Komputindo.

Salbino, Sherief, 2014. Buku Pintar Gadget Android Untuk Pemula. Jakarta: Kunci Komunikasi.

Sidiq, Anwar. 2017. Pemanfaatan Instagram Sebagai Media Dakwah (Study Akun @afuadbakh). Lampung.

Sulton, 2003. Desain Ilmu Dakwah kajian Ontologis, Epistemologis dan Aksiologis. Semarang: Pustaka Pelajar.

Suparta, Munzier, 2009. Metode Dakwah, Jakarta: Kencana.

Suyanto, Bagong, 2011. Metode Penelitian Sosial Berbagai Alternatif Pendekatan, Jakarta: Kencana Media Group.

Syukir, Asmuni, 1993. Dasar-dasar Strategi Dakwah. Surabaya: AL-Ikhlas.

Tamburaka, 2012. Literasi Media Cerdas Bermedia Khalayak Media Masa. Jakarta: Raja Grafindo Persada.

Tubbs, Stewart L. 2000. Human Communication. Bandung: Rosda Karya

Usman, Fadly. 2016. Efektivitas Penggunaan Media Online Sebagai Sarana Dakwah. Malang: Jurnal Ekonomi dan Dakwah Islam Al-Tsiqoh.

Wahid, 2016. Komunikasi Politik Teori Konsep dan Aplikasi pada Era Media Baru. Bandung: Remaja Rosdakarya Offset.

Wikipedia, diakses 7 September 2019 pukul 00.02 .

Zaidan, Karim Abdul, 1983. Dasar-dasar Ilmu Dakwah, Jakarta: Media Dakwah. 